\title{
Ahmed Shawqi And Educational Poetic Stories On The Tongues Of The Animals
}

\author{
Nada Yousuf Al-Rifai (2015) \\ College of Basic Education, PAAET, Kuwait.
}

Ahmad Shawqi (1868-1932) was one of the finest Arabic-language poets and dramatists to pioneer the modern Egyptian literary movement, most notable for introducing poetic epics to the Arabic literary tradition. Shawqi also produced distinctive poetry that was widely considered the most prominent of $20^{\text {th }}$-century Egypt.

Shawqi's work at the palace played a great role in facilitating ways to gain information, knowledge, and access to European arts, as the Khedive sent him to Europe to learn about both French and English literature. He translated some literary works, such as Lamartine's poem, "The Lake." Shawqi was also pleased by La Fontaine's poetry and fables. Thus, he was influenced by the French poets in their dealings with new subject matter and their ways of forming their poems. He also took advantage of what he learned in France in choosing new topics, bringing them out in an innovative and exquisite manner; he blended heritage with language, style, music, and imagination and presented them in a smooth Egyptian spirit, which fit emerging Arab tastes (Al-Sheikh, 2006).

Ahmad Shawqi (the Prince of Poets) did not leave any section of poetry without writing in it with the same excellence and quality, whether in the field of description, pride, wisdom, philosophy, congratulation, praise, or lament. Shawqi even wrote simplified children's poetry, which included themes of wisdom, love, and humanity (Abd Ul-Majeed, 1998, page 111).

Ahmad Shawqi was, by virtue of his morals, a very tender personality, close to the pure essence of the world of childhood, a world of innocence, emotion and beauty; Shawqi loved childhood greatly.

Dr. Shawqi Daif said, "poetry and singing united in Shawqi, and everything in him prepared him for that, as he was an admirer of singing and singers on the one hand, while his poetry had a magical musical sweetness on the other hand ... There is no doubt that this had an effect on Shawqi's poetry, not in terms of authorship of the songs, but also in terms of selecting the words. Shawqi did not mean in his songs to amuse himself only and his singer, but also intended to please the mass audience and this aim, which Shawqi was unable to get rid of, made him descend from the high sky of his eloquent words, which he usually elected in his poems, into easy words that would go on every tongue." (Daif, 2010, pages 167-168).

Shawqi's national interest circle widened to include children, as he felt they had a right to their own literature that would take them by their hands. He wrote for them more than fifty tales in simple, easy poetry, to make them love their language, nourish their imagination, and consolidate human values within them (Ismail, 2003).

Ahmed Shawqi and the call for children's literature: 
The poet Ahmad Shawqi said in the introduction to his poetry collection "Al-Shawqiyat,"It occurred to my mind to write anecdotes in the same famous La Fontaine style, and in this collection there are some of them." ..."I wish that God would help me to make for the Egyptian children - as poets made for children in advanced countries- poems that are close to them, from which they could gain wisdom and good manners according to their understanding." (AlShawqiyat)

Shawqi composed poetic stories on the tongues of the animals. He composed these tales in an easy and attractive manner and narrated 56 of those tales, the first of which was published in the newspaper "Al-Ahram" in 1892, entitled "Al-Deek Al-Hindi wa Al-Dajaj Al-Baladi" (The Indian Rooster and the Local Chicken); the story symbolized the occupying forces and Egypt (Hashim, 2013).

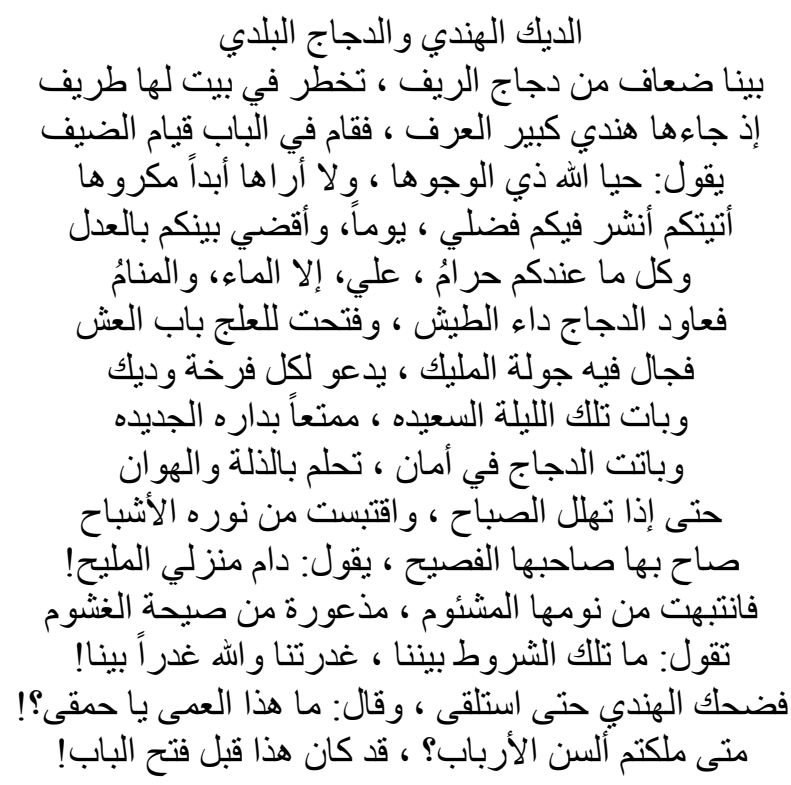

The Indian Rooster and the Local Chickens

While some weak rural chickens were strutting about their nice home, There came to them a large-combed Indian rooster, who stood by the door like a guest.

He said, "May God grant a long life to these visages, never showering them with misfortune. I come to you for just one day, to spread my virtue to you, and judge between you in justice.

All that you own is forbidden to me, except water and sleep."

Recklessness revisited the chickens, and they opened the door for the tough foreigner.

He walked around their house like a king, praying for every hen and rooster.

He stayed over that happy night, enjoying his new house.

The chickens spent the night in safety, dreaming of submission and humiliation.

So when the morning rejoiced, and the objects quoted from its light,

The eloquent owner shouted out, saying: "Long live my lovely house"

The chickens woke from their ill-fated sleep, panicking from the wanton cry.

Saying, "Those weren't our conditions! Obviously you've betrayed us! "

The Rooster laughed till he fell back and said: "What is this blindness, 0 fools?!

Since when did you own the tongues of lords? This was before you opened the door!

The poet's content crystallized into the following frames, respectively (Zalat, p168-169):

1. The political significance (in tales that portray politicians and policy affairs, rulers and the royal court). 
2. The moral educational significance (in tales that deal with behavioral and educational values and wisdom literature).

3. The national significance (in tales related to the growth of national consciousness and national resistance to the occupier).

4. The humorous and social significance (in poetic anecdotes, which tend to appropriate humor and hidden symbols).

Shawqi excelled in an interesting dialogue between two birds and a wind coming from Yemen, presenting an eloquent lesson on the topic of loving homeland:

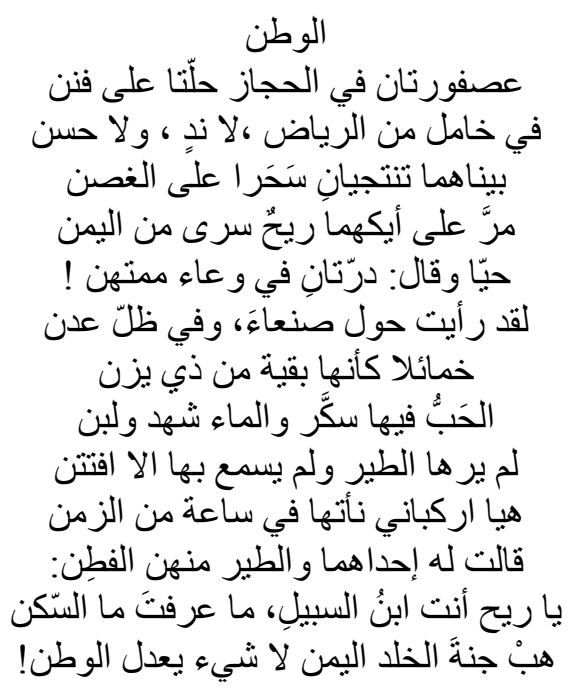

Homeland

Two birds in Al-Hejaz perched on a branch

In a dull garden that was dewless and without beauty.

While they were twittering on the bough in the early morning,

A wind coming from Yemen passed them by.

It saluted them and said: "Two pearls in a contemptible container!

I have been around Sana'a, in the shade of Aden,

Delightful gardens, as if made for Dhi Yazan's rest

With seeds like sugar and water like milk and honey

No bird has seen or heard them without being enthralled

Come mount me to reach it, within an hour's time."

One of the two birds answered, since some birds are astute:

"O Wind, you are a wanderer, never have you known what a home is.

Even if Yemen was the eternal paradise,

nothing equals the land called 'home'!

The heroes of Shawqi's tales are typically animals; the lion is a symbol of power, the wolf of slyness and authoritarianism, the dog of honesty and loyalty, the fox of elusion, and the ass of stupidity and submissiveness. Birds like the hoopoe, dove, pea rooster, lark, pigeon, parrot, and others were also mentioned in his poetry.

$$
\begin{aligned}
& \text { ولي عهد الأسد وخطبة الحمار: }
\end{aligned}
$$

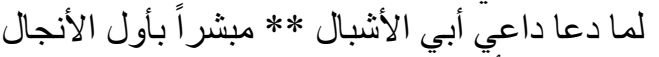

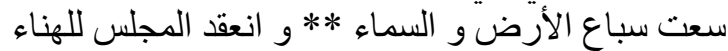

$$
\begin{aligned}
& \text { و صدر المرسوم بالأمان ** في الأرض للقاصي بهاو العة الدجلي لإني }
\end{aligned}
$$




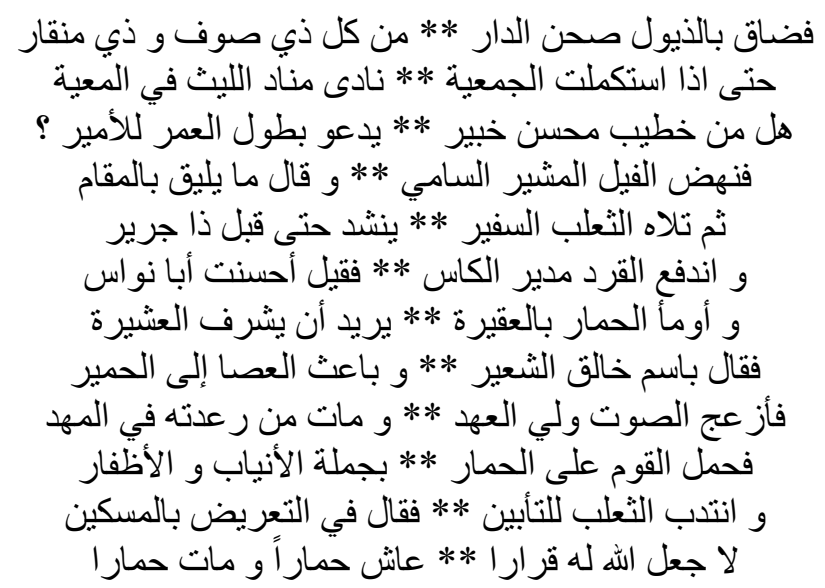

The Lion's Crown Prince and the Ass's Speech

Celebrating his first son's birth, the cubs' father invited

All the animals and birds came, and the happy assembly was held.

A decree of safety was issued throughout the land, for the near and the far

Until there was no place left in the courtyard for the tail holders, some with wool and others with beaks.

When the Assembly completed, the Lion's caller called:

"Is there an expert speaker, who would pray for a long life for the prince?"

High Marshal, the elephant, got up and said what befitted the occasion.

Then he was followed by Ambassador, the fox, who recited like a rhymester.

Then rushed in the monkey, Manager of the Cup, who was told "Well done, versifier".

The ass nodded, asking for permission, wishing to honor the clan.

He said: "In the name of the barley's creator, the sender of switches for asses."

His clamoring so annoyed the crown prince, he died of fear in the cradle.

The clan folk took on the ass with their fangs and claws.

The fox was assigned the eulogy and, indicating the poor fellow, said,

"May his soul not rest in peace, he lived as an ass and died as an ass."

Shawqi also made use of famous men of religious history and prophets in his tales. Prophet Solomon and Prophet Noah (peace be upon them) had great power over the animal world, as stated in the Holy Quran. Shawqi utilized that Quranic source, portraying these events in a symbolic way to make them equivalent subjects of the events that took place in the country (Abdul-Wahab, 1987, page 219).

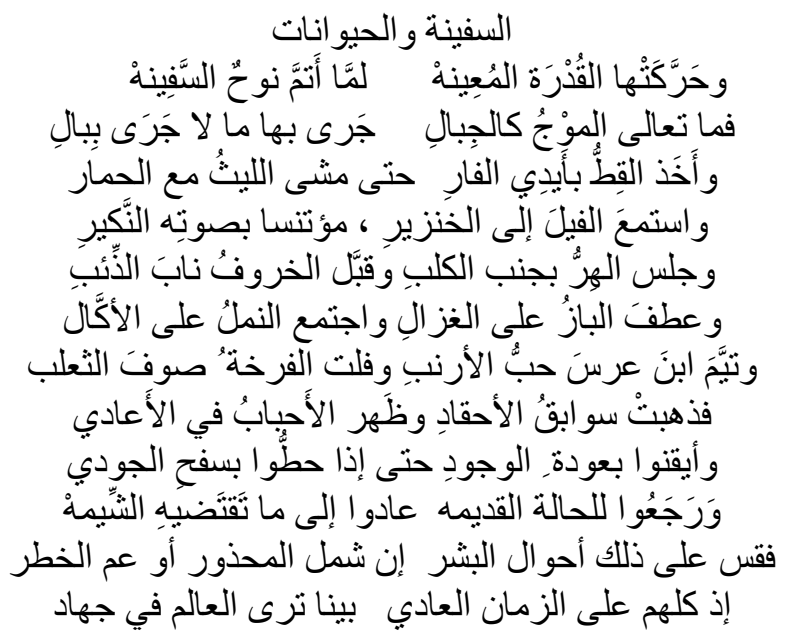


Noah's Ark and the animals

When Noah completed the ship, it moved by the supporting omnipotence.

What happened within it has never occurred to the mind of man;

From the moment the waves towered up like mountains,

the lion walked with the donkey,

and the cat took the hand of the mouse.

The elephant listened to the pig,

being entertained by his detestable voice.

The cat sat beside the dog, and the sheep kissed the wolf's fang.

The falcon was kind to the gazelle, and the ants gathered with their eater.

The hen sorted through the fox's wool, and the weasel fell in love with the rabbit.

Their former hatreds departed, and all appeared as loved ones, no longer enemies, that is

Until they landed on Mount Judi and became certain of their future survival.

Then they went back to their old acquired habits, and returned to their old ways.

Accordingly, compare this to the human condition when adversity includes all or danger prevails.

When you see the world struggling, it is fighting against its opponent, time.

In Shawqi's poetic tales regarding Prophet Solomon, peace be upon him, with the hoopoe, pea rooster, and dove, Shawqi used these tales to highlight their elements as symbols of what he wanted to express, regardless of their incidents. In one of them, Shawqi says:

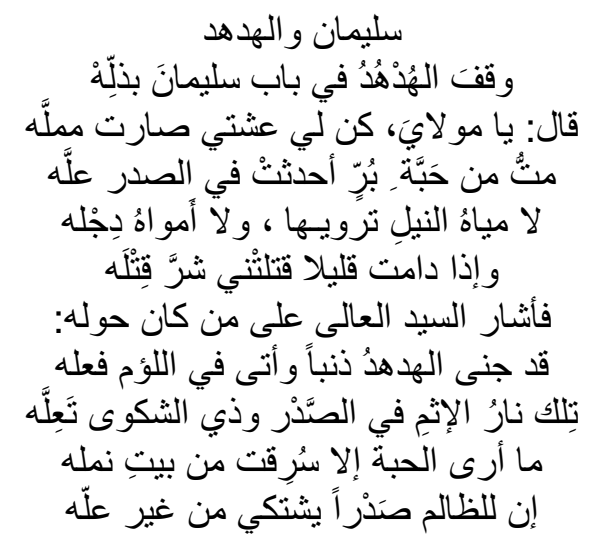

Prophet Solomon and the Hoopoe:

The hoopoe stood submissively at Solomon's door,

He said: 0 lord, help me, my life became boring,

I am dying of a wheat grain, which brought illness to my chest.

Neither the Nile's water nor the Tigris' would quench it.

If it lasts a little more, it will kill me.

The high master pointed out to those who were around him:

The hoopoe has committed a sin, and his deed was an act of meanness,

That is the fire of $\sin$ in the chest, and this complaint is nothing but an excuse.

I only see that the grain was stolen from an ant's house

The wrongful has a chest, that complains without an illness.

Shawqi inserted wisdom in his poetry to strengthen its poetic structure to be used for direct preaching or conclude his tales. Wisdom was delivered in Shawqi tales by the tongues of some of its heroes, totally merged and naturally generated. 
Shawqi was able to bring out his tales in a theatrical way, based on a dialogue that included lightness and vitality to make it more effective and nearer to the reader (Abdul-Wahab, 1987, pages 221-223).

Among the tales of "Kalīlah wa Dimna" (Panchatantra) that influenced Shawqi was the tale of (The Fox and the Rooster), a fictional tale from which Shawqi meant to teach children how to resist the liars and cheaters who lure people and mislead them. Shawqi said, photographing this scene (Al-Sheikh, 2006, page 60):

The fox's image, as Ahmad Shawqi presents it, is in its usual cunning nature of deception and slyness, as pictured by Lafontaine. Yet the fox's trickery on the rooster, courting him through his "repentance," is a bit different in the position of Shawqi's tales due to the absence of the two dogs in Lafontaine's story, followed by Jalal Othman. The lesson of the story was summarized in the last line of the poem (Zalat, page162). In this symbolic story (The Fox and the Rooster), there is a reference to the cunning and deception of those who fake religiosity and a call not to have confidence in them:

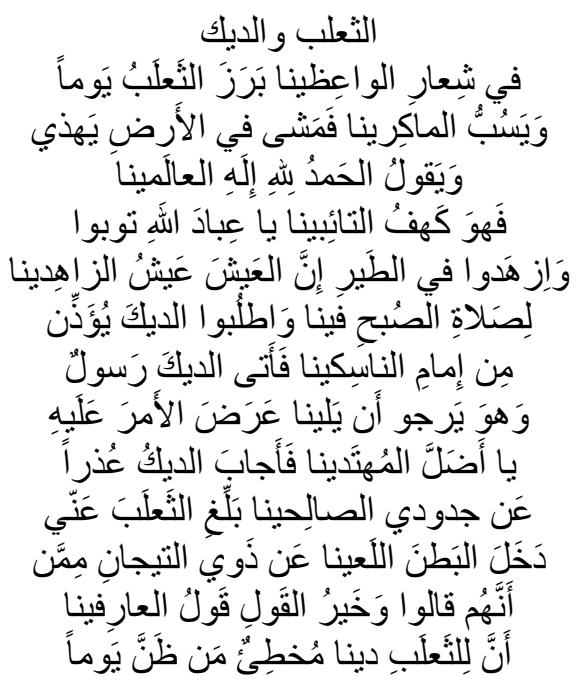

The Fox and the Rooster

One day, the fox emerged, holding the preachersPJ' logo.

Walking on earth, guiding and cursing the cunning.

Saying: praise be to Allah, the Lord of the universe.

0 slaves of Allah, repent! As it is the cave of the repentant.

Renounce the birds, as real life is the life of the ascetics.

Ask the cook to wake us for morning prayer.

The rooster received the hermits' leader's messenger,

Who presented the affair to him, hoping that he would agree.

Sorry, replied the rooster, o most astray of all the guided.

Tell the fox, on my behalf, and on the behalf of

my virtuous crowned grandparents, who entered the cursed belly.

It was said, and the best words are those of the knowledgeable:

Mistaken is he who thought, one day, that the fox has a creed.

This is how Shawqi's poetry presents the tales in a simple poetic style characterized by smoothness, consistency of ideas, and reliance on the whole image, which is composed of partial images contributing to the formation of the essence of the artwork, offered in a dramatic way (Al-Sheikh, 2006, page 61). 
Shawqi also emphasizes the consequences of foolishness, vanity, and not listening to the advice of the others. He also emphasizes the value of "essence before appearance," as appearances are lustrous but deceiving. Thus one should not rush behind the false sparkling, yet rather behind the right idea and proper essence, even though the talker was a black slave. In one of his witty poems, "The Bat and the Butterfly Queen," he said:

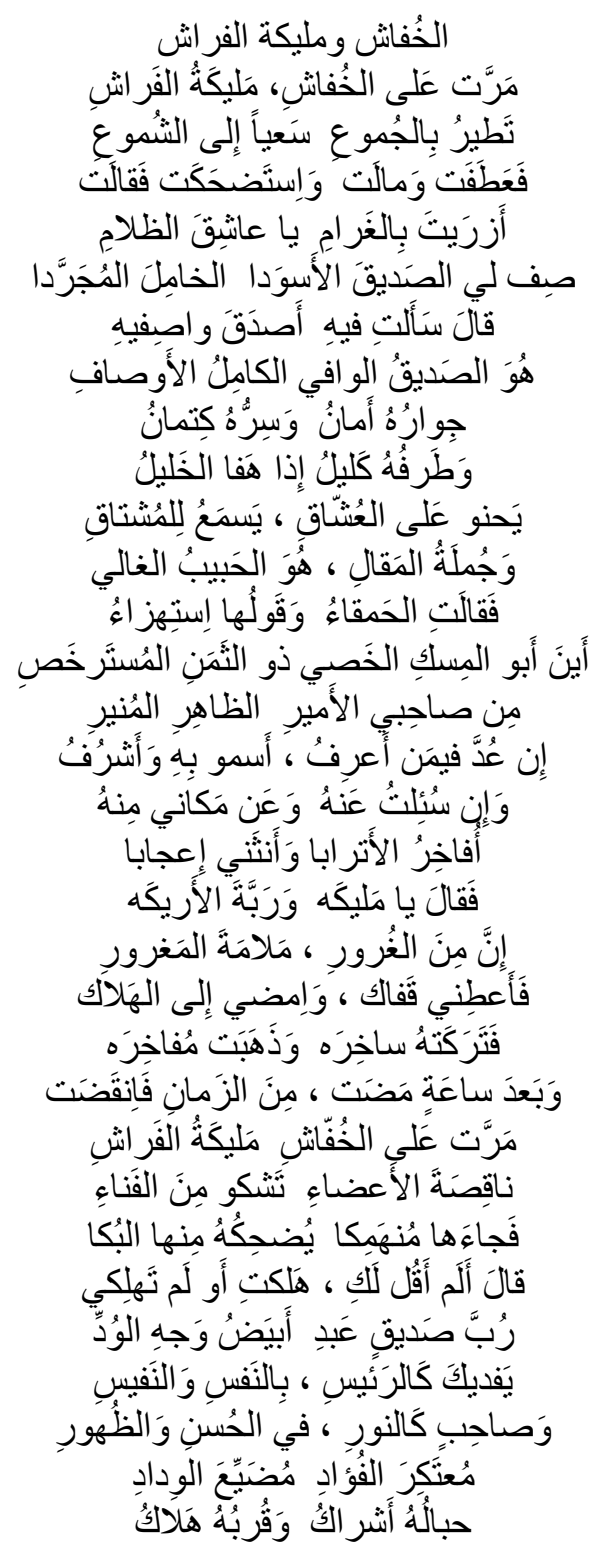

\section{The bat and the butterfly queen}

The butterfly queen, passed by the bat,

Heading the flocks in search of candles.

She bent and leant, then laughed and said:

0 darkness lover! Have you been derogated by love?

Describe to me the sluggish naked black fellow.

He said: you've asked about him, the one who could best describe him.

He is the sufficient friend, with perfect attributes.

His neighborhood is safety, his secret is concealment.

With sleepy eyes, when the comrade floats nearby.

Kind is he to lovers, listening to their longing. 
And all in all, he is the cherished love.

She the foolish, said mockingly:

How far is the cheaply priced, musk eunuch, from my friend,

the apparent enlightening prince!

When counted among whom I know, I feel highly risen and proud of him.

And when asked about him, and my position to him;

I boast to my peers, and bend in admiration.

He said: your majesty, the throne holder.

It is in vain to blame an arrogant.

So turn away from me, and go to your perdition.

She left him, mocking at him, and went away boasting.

After an hour had passed away,

The butterfly queen, passed by the bat,

with missing parts, almost dead.

He engrossedly came to her, laughing at her tears.

Saying: Whether alive or dead, didn't I tell you?

Many a black slave friend has a white loving face,

and ransoms you as his leader, by his soul and every precious thing.

While a shining friend, with a beautiful appearance

holds a turbid heart, his cordiality is wasted.

His ropes are but a trap, his closeness is perdition.

In the story of "The crows' king and the servant Nedour," Shawqi confirms that he who does not follow the advice of his predecessors and make use of their experience will perish or get dreadful consequences. He also confirms in the story that nothing remains as it is; therefore, Shawqi says that man must be content and pleased by the advice and should take precautions and beware of the ominous things without arrogance and vanity when facing situations.

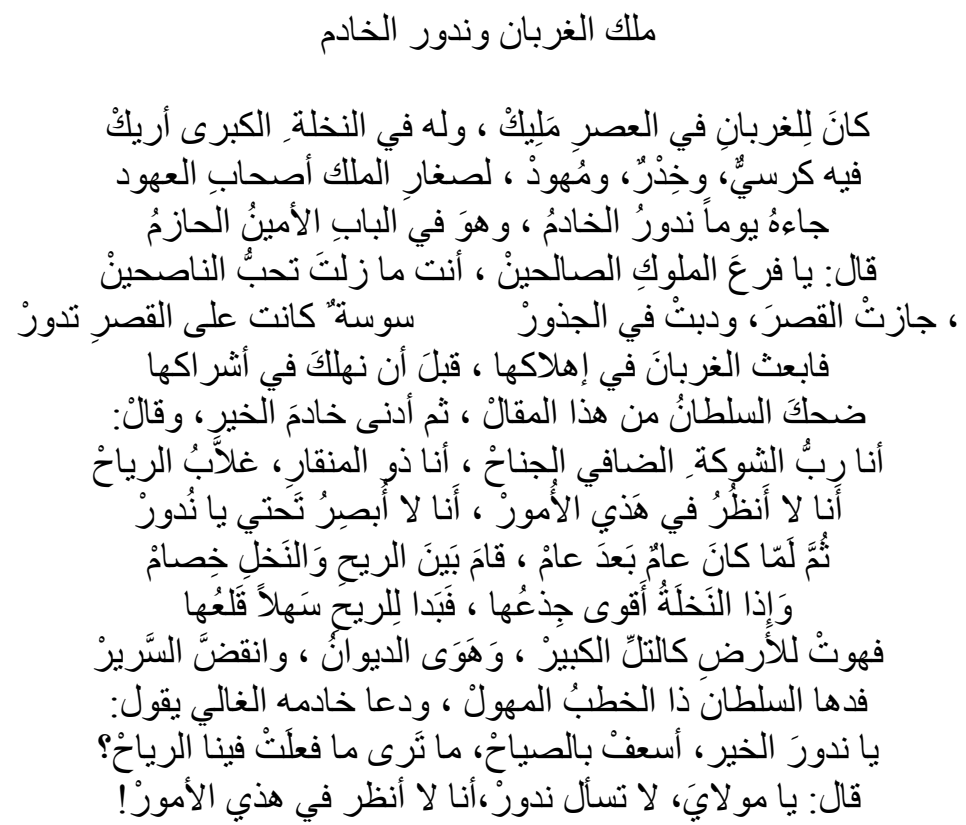

\section{The crows' king and the servant Nedour}

Once upon a time, the crows had a king, who had a throne on the greatest palm.

On it was a chair, a boudoir, and cots for the young crown princes.

One day came Nedour, the servant, standing honestly and firmly by the door.

He said: $\mathrm{O}$ branch of the righteous kings, you still love the advisers 
A mite was spinning by the palace, passed through it, and crept into the roots.

So send the crows to wipe it out, before we perish by its traps.

The Sultan laughed at this saying, then brought the good servant near him, and said:

I am the Lord of the thorn, with my abundant wings, I am the billed wind conqueror!

"I do not look into these matters, I do not see below me, Nedour."

Then passed a year after a year, during which a quarrel arose between the wind and the palm tree.

The palm's trunk was no longer strong, hence, easily uprooted by the wind.

It fell to the ground like a large hill, the couch, the bed, all went to ground.

The Sultan, astounded by the appalling disaster, he called his dear servant, saying:

Oh good Nedour, help by shouting! Can't you see what the wind has done to us?

He said: O lord, do not ask Nedour, "I do not look into these matters."

It can be said that the collection of the poetic stories created by The Prince of Poets, Ahmad Shawqi, included a group of behaviorally and morally fine concepts and educational values, representing embedded wisdom within them every now and then. He composed them in a symbolic manner, perhaps to be funnier and more charming for children than if the words were uttered by human beings, and to achieve the educational goal for which he wrote them for, indirectly, because human nature usually hates direct advice. There is no doubt that these poetic stories on the tongues of the animals reflect the talent and aptitude of this great poet.

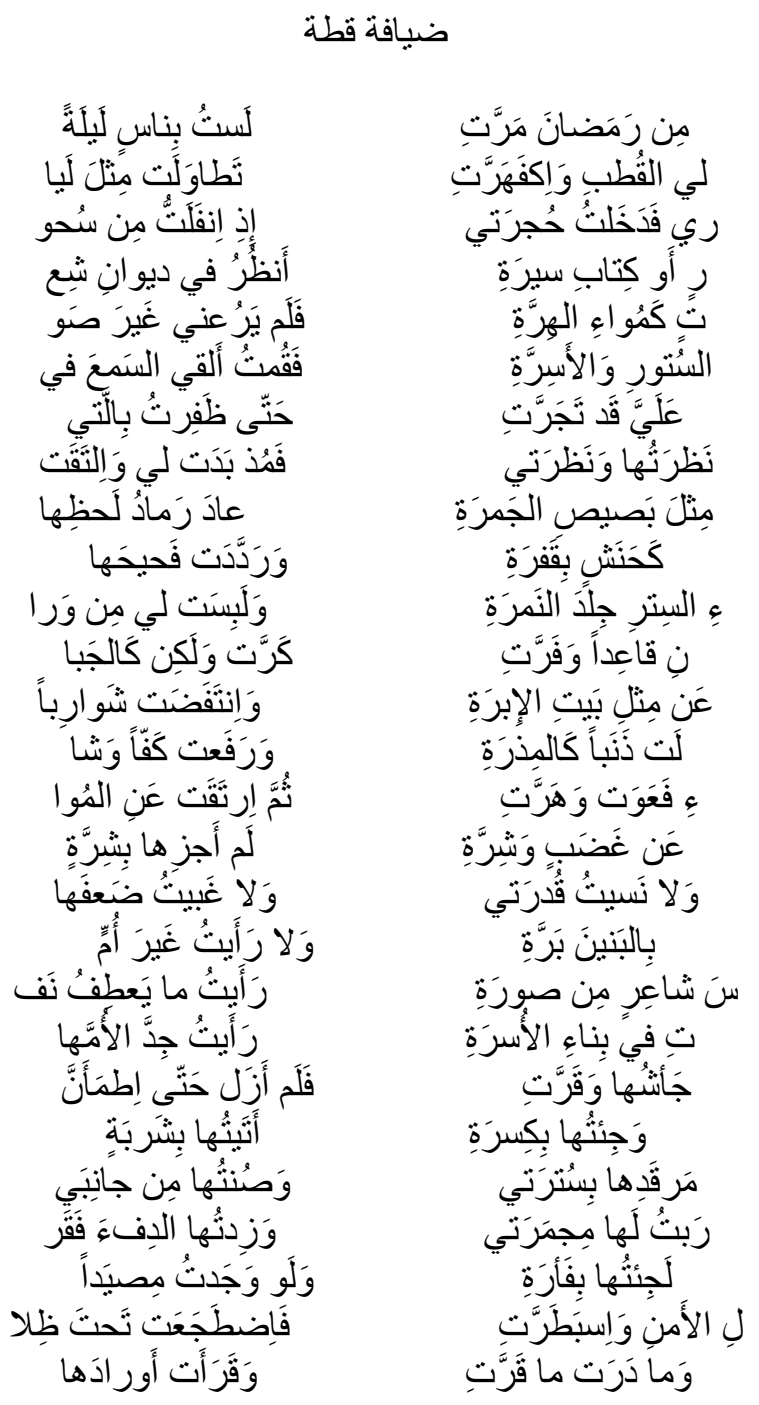



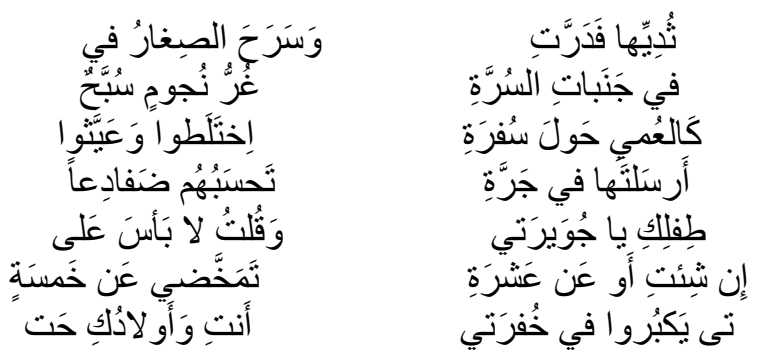

Hosting a Cat

I won't forget a night that passed during Ramadan, the month of fasting

It lengthened and darkened like a polar night

I finished my last meal before fasting and entered my room

As I was browsing through a poetry collection or biography

I was frightened by a voice like a cat's mewing

I stood up to lay my eyes on what was between the curtains and beds

Till I found the one who dared me

The moment she appeared to me and my gaze met with hers,

the fire in her glance returned to me like lightning

She hissed again, like a snake in the wilderness

and wore behind the curtain, a tigress's skinShe charged, yet like a coward, she then reversed

She stuck out her whiskers, and her hair rose like a pincushion

She lifted a paw and raised her tail like a duster

Then she elevated her voice into a howling and growling

I did not answer her anger and hatred with anger

Or misjudge her weakness or forget my strengths

I saw in her only a devoted mother

And glimpsed what made a poet's soul sympathize with an image

I saw a mother's diligence in raising her family

And stayed with her until she was reassured and settled

I brought her something to eat and drink

And protected her by my side, making a bed of my jacket for her

I warmed her by narrowing my brazier near her

Had I a trap, I would have brought her a mouse

She stayed in the shade of my security and eventually lay down,

Purring her prayers, though unaware what they were

Her young kittens indulged themselves in her nipples, thus they poured out

They were unmindful, like the stars, revolving around her belly

They were like the blind, mingling and ravaging the food on a dining table

Looking like frogs in a jar

I told her, “Don't worry about your children, my little neighbor

You can give birth to five or ten more if you wish

You and your kittens will remain in my guard till they too are cats."

\section{References}

Abdul-Wahab, S. (1987). Islamiyat Ahmad Shawqi. Maktabat Madbouli: Cairo, Egypt.

Al-Sheikh, H. (2006). Jadalliyat Al-Turath fe She'r Shawqi Al-Ghina'ie. Al-Maktab Al-Jami'e Al-Hadeeth: Alexandria, Egypt.

Daif, S. (2010). Shawqi Poet of the Modern Time. Dar Ul-Ma'aref: Cairo, Egypt.

Hashim, M.A. (2013). Fi Mada'in alf layla wa Layla (In the towns of One Thousand and One Nights). Kuwait Magazine 358. 
Ismail, I.U. (2003), Prospects of modern and contemporary Poetry in Egypt. Dar Ghareeb: Cairo, Egypt. Shawqi, A. (n.d.). Al-Shawqiyat. Dar Al-Ketab Al-Arabi: Beirut, Lebanon.

Ul-Majeed, A.A. (1998). Shawqi Al-Insaan. Dar Ul-Ma'aref: Cairo. Egypt.

Wahab, S. A. (2006). Shawqi fi Oyoun Mu'asereh (Shawqi in the eyes of his contemporaries). Kuwait: The Foundation of Abdulaziz Saud Al-Babtain's Prize for Poetic Creativity.

Zalat, A. (1994). Children's Literature between Ahmad Shawqi and Othman Galal. Al-Wafa library, Al-Mansoura, Egypt: Publishing House of Egyptian Universities. 